\title{
DAIRY PRODUCTION OF 'SAANEN' GOATS BASED ON METEOROLOGICAL VARIABLES AND FUTURE CLIMATE SCENARIOS
}

Doi:http://dx.doi.org/10.1590/1809-4430-Eng.Agric.v37n2p226-235/2017

\section{IZAAC D. PEQUENO ${ }^{*}$, SILVIA H. N. TURCO ${ }^{2}$, THIERES G. F. DA SILVA ${ }^{3}$ OLIVARDO FACÓ 4}

\author{
${ }^{1 *}$ Corresponding author. Companhia de Desenvolvimento dos Vales do São Francisco e do Parnaíba-Codevasf/ \\ Petrolina - PE, Brasil. E-mail: izaac.pequeno@codevasf.gov.br
}

\begin{abstract}
This study aimed to modeling and bioclimatic zoning of 'Saanen' goat milk production in northeastern Brazil. Data were obtained from a 14-year dairy control program for 246 'Saanen' goat matrices. Dairy production meteorological influence and mathematical modeling were assessed through statistical analyses such as Pearson's correlation matrix and path analysis. Bioclimatic zoning for current and future scenarios, with climate changes, were delineated using inverse-square distance (ISD) and spherical model (kriging) interpolations. Results showed maximum air temperature to contribute substantially to goat dairy production; therefore, its modeling was based thereon. Current and future dairy production maps highlighted Maranhão and Piauí as regions of limited 'Saanen' milk production. Furthermore, we should emphasize that temperature rises in further scenarios may have significant impact on the potential of dairy farming for the region under study.
\end{abstract}

KEYWORDS: path analysis, welfare, stress, climate change.

\section{INTRODUCTION}

Dairy goat farming is a high-profile activity for farms in the northeast of Brazil. Despite the increasing productivity (GEROSA \& SKOET, 2012) and ongoing technological advances in management, genetics, and ambiance, it still needs improvement to enhance its economic feasibility.

For advances in dairy goat farming, specialized breeds, such as 'Saanen', have been introduced into the northeastern Brazil. Nonetheless, these breeds' adaptability relies on the response of a set of physiological adjustments to local climatic conditions, thus playing direct and indirect roles on animal production performance (PEREIRA et al., 2011; SILVA et al., 2011; SANTOS et al., 2014). This way, knowing how meteorological variables influence milk production has high priority for evaluations of Brazilian northeast climatic potential and further advancing of the dairy goat farming beyond the agricultural boundaries in this region.

Several climatic indexes have been used to establish criteria for thermal comfort rating of an environment onto the livestock activities. Nevertheless, the lack of a specific indicator for each species or breed has led to the use of bioclimatic indexes of other species, such as those proposed by THOM (1959) and BUFFINGTON et al. (1977).

As an alternative to these indexes, correlation matrix and path analysis become essential tools to associate animal production features and environmental variables. By using these techniques, both direct and indirect effects of an explanatory variable on a response variable can be identified (WRIGHT, 1921).

In northeast Brazil, livestock performance has already been associated with meteorological variables by means of bioclimatic indexes for bioclimatic zoning of dairy cows (SILVA et al., 2009) and sheep (MENDES et al., 2014), in the state of Pernambuco.

\footnotetext{
${ }^{2}$ Universidade Federal do Vale do São Francisco - UNIVASF/ Juazeiro - BA, Brasil

${ }^{3}$ Universidade Federal Rural de Pernambuco - UFRPE/ Serra Talhada - PE, Brasil.

${ }^{4}$ Empresa Brasileira de Pesquisa Agropecuária - Embrapa/ Sobral - CE, Brasil.

Received in: 4-8-2016

Accepted in: 10-17-2016
} 
Dairy goat bioclimatic zoning in northeastern Brazil represents an important step for this activity given its wide climatic variation. With this, most suitable areas could be identified, providing an adequate management and favoring maximum genetic performance of animals. Such improvement would mainly aid in mitigating climate change scenarios, thus, grounding advances towards the agricultural frontiers.

Based on the above, we aimed to draw up a mathematical model for estimation of 'Saanen' goat dairy production, with further delineation of a bioclimatic zoning for northeast Brazil.

\section{MATERIAL AND METHODS}

The study was divided into three stages. First, dairy production data of 'Saanen' goats and local meteorological variables underwent statistical procedures for identification of associations between them and, then, setting a mathematical model for daily milk yield estimation at a lactation peak. Secondly, this mathematical model was applied to the climatological database for bioclimatic zoning of goat dairy farming within the northeast of Brazil. Finally, a third stage consisted of making future projections for climatic variables, simulating climate change scenarios.

Dairy records were gathered from 'Saanen' goats belonging to the Embrapa Caprinos $e$ Ovinos, in Sobral - CE, Brazil. Every 14 days, dairy control was conducted, between 1998 and 2011, for animals in semi-confinement (rainy season) and in confined (dry period) regimes. Altogether, we sampled 246 goat matrices.

For analysis, we gathered data from matrices with until three parturitions, early milk production above one liter per day, and weighing at least 50 kilos (live weight). All of these animals were lactating between 50 to 200 days, being thus 25 animals.

We investigated the effect of meteorological variables on milk production, using mean data of milk production at peak lactation. That way, the effects of lactation curve on daily milk production could be eliminated. Besides, we assumed this phase as the one of great animal sensitivity to environmental conditions and handling.

The meteorological variables to be assessed were rainfall $(\mathrm{R}, \mathrm{mm})$; mean, maximum, and minimum air temperatures $\left(\mathrm{T}_{\mathrm{m}}, \mathrm{T}_{\max }\right.$, and $\left.\mathrm{T}_{\min },{ }^{\circ} \mathrm{C}\right)$; air relative humidity $\left(\mathrm{RH}_{\mathrm{m}}, \%\right)$; wind speed (WS, $\mathrm{m} \mathrm{s}^{-1}$ ); and sunshine $(\mathrm{S}, \mathrm{h})$. These data were acquired from a conventional meteorological station, in Sobral - CE, at the experimental area of Embrapa Caprinos e Ovinos, and from a database for Teaching and Research (BDMEP) referring to the historical series recorded by meteorological station network of the Brazilian Institute of Meteorology (INMET).

By means of these resources, temperature and humidity index (THI) (THOM, 1959), black globe temperature and humidity index (BGTHI) (BUFFINGTON et al., 1977), photoperiod (PH, h), global solar radiation ( $\mathrm{Rs}, \mathrm{W} \mathrm{\textrm {m } ^ { - 2 }}$ ), vapor pressure deficit (VPD, $\mathrm{hPa}$ ) (VIANELLO \& ALVES, 2012), and black globe temperature (BGT, ${ }^{\circ} \mathrm{C}$ ) were estimated (TURCO et al., 2008).

A Pearson's linear correlation coefficient matrix was determined using dairy production data at lactation peak (response variable) and meteorological variables (explanatory variables). The magnitude of this matrix was classified as follows: (r) 0 to 0.19 "very weak"; (r) 0.20 to 0.39 "weak"; (r) 0.40 to 0.69 "moderate"; (r) 0.70 to 0.89 "strong"; and (r) 0.90 to 1.00 "very strong", as proposed by THOMAZ et al. (2012). Next, we used this matrix to diagnose multicollinearity, aiming at eliminating explanatory variables linearly related to each other.

The diagnosis was established based on the number of conditions, which is the ratio between major and minor correlation matrix eigenvalue. When this number is less than 100, multicollinearity is weak; if between 100 and 1,000, it is moderate to strong; and finally, it is severe if greater than 1,000. These last two classes dropped the variables out of the next step when correlations are decomposed into direct and indirect effects, through path analysis.

All statistical procedures were carried out using GENES software (CRUZ, 2013). Those meteorological variables that had the highest influence on dairy production were used for linear or 
non-linear simple or compound mathematical modeling, through Sigmaplot software, v.10. Model and variable significance were given based on ' $\mathrm{t}$ ' Student and $\mathrm{F}$ tests and considered valid as long as significant at $5 \%$ probability.

The resulting mathematical model was applied to a climatic database of observed and estimated data from 1,857 observation posts throughout the northeast region. Of these, 74 are main meteorological stations belonging to the INMET, and the others are rain-gauge stations which are part of the hydrometeorological network of the Northeast Development Authority (SUDENE). These only have rainfall data, monthly values of global solar radiation, temperature (maximum, minimum, and average) and relative air humidity according to procedures suggested by BRISTOW \& CAMPBELL (1984), CAVALCANTI et al. (2006), and SILVA et al. (2007), respectively. Future projections of climate change were incorporated into the database in two scenarios B2 (more optimistic) and A2 (more pessimistic). These scenarios were based on assumptions of the Intergovernmental Panel on Climate Change (IPCC), described by Nakicenovic et al. (2000). The Providing Regional Climates for Impact Studies (PRECIS) model, generated by the National Institute for Space Research (INPE), furnished the regionalized climate data. Dairy production results for both current and future scenarios were regionalized through ArcGIS 9.3 software by inverse-square distance (ISD) and spherical model interpolation, as suggested by SILVA et al. (2007).

\section{RESULTS AND DISCUSSION}

Results showed that most of the climatic variables $\left(\mathrm{R}, \mathrm{T}_{\mathrm{m}}, \mathrm{T}_{\mathrm{max}}, \mathrm{RH}_{\mathrm{m}}, \mathrm{Rs}\right.$, THI, BGT, BGTHI, and VPD) had moderate to strong correlation with the dairy performance of 'Saanen' goats, with (r) between $|0.56|$ to $|0.87|$. After multicollinearity analysis, $\mathrm{R}$ (moderate) and $\mathrm{RH}_{\mathrm{m}}$ (strong) presented positive and significant correlations with milking performance, indicating an increase in production during rainy periods. However, negative correlations were observed for $\mathrm{T}_{\max }$ and $\mathrm{Rs}$, being strong and significant.

The indexes THI and BGTHI were unsuitable for thermal stress analysis in 'Saanen' goats. Although these indexes had a correlation with milk production, they showed high multicollinearity with meteorological variables. It can be explained because the used models are empirical, being developed for cattle (BUFFINGTON et al., 1977; THOM, 1959); therefore, they may not be able to detect dairy goat responses to the environment, defeating the individual effect of the variables.

The direct and indirect effects derived from correlation coefficients of significant explanatory variables by path analysis revealed that both direct and indirect effect of $\mathrm{T}_{\max }$, via $\mathrm{R}, \mathrm{RH}_{\mathrm{m}}$, and $\mathrm{Rs}$, was the variable that most contributed to the reduction of dairy production in 'Saanen' goats (Table $1)$. 
TABLE 1. Statistical breakdown of the correlations into direct and indirect effects of rainfall, maximum air temperature, relative humidity, and global solar radiation on the dairy production of 'Saanen' goats. Desdobramento das correlações dos efeitos diretos e indiretos da precipitação, temperatura máxima do ar, umidade relativa do ar e radiação solar global sobre a produção de leite de cabras Saanen.

\begin{tabular}{|c|c|c|c|}
\hline Meteorological variable & $\begin{array}{l}\text { Correlation } \\
\text { coefficient }\end{array}$ & Meteorological variable & $\begin{array}{l}\text { Correlation } \\
\text { coefficient }\end{array}$ \\
\hline Rainfall & & Air mean relative humidity & \\
\hline Direct effect on milk production & -0.12 & Direct effect on milk production & -0.52 \\
\hline $\begin{array}{l}\text { Indirect effect via maximum air } \\
\text { temperature }\end{array}$ & 1.16 & Indirect effect via rainfall & -0.91 \\
\hline $\begin{array}{l}\text { Indirect effect via air relative } \\
\text { humidity }\end{array}$ & -0.41 & $\begin{array}{l}\text { Indirect effect via maximum air } \\
\text { temperature }\end{array}$ & 1.45 \\
\hline $\begin{array}{l}\text { Indirect effect via global solar } \\
\text { radiation }\end{array}$ & -0.03 & $\begin{array}{l}\text { Indirect effect via global solar } \\
\text { radiation }\end{array}$ & -0.27 \\
\hline Total & 0.61 & Total & 0.81 \\
\hline Maximum air temperature & & Global solar radiation & \\
\hline Direct effect on milk production & -1.52 & Direct effect on milk production & 0.47 \\
\hline Indirect effect via rainfall & 0.09 & Indirect effect via rainfall & 0.71 \\
\hline $\begin{array}{l}\text { Indirect effect via air relative } \\
\text { humidity }\end{array}$ & 0.49 & $\begin{array}{l}\text { Indirect effect via maximum air } \\
\text { temperature }\end{array}$ & -1.16 \\
\hline $\begin{array}{l}\text { Indirect effect via global solar } \\
\text { radiation }\end{array}$ & 0.04 & $\begin{array}{l}\text { Indirect effect via air relative } \\
\text { humidity }\end{array}$ & 0.07 \\
\hline Total & -0.90 & Total & -0.74 \\
\hline$\overline{\text { Coefficient of determinat }}$ & 0.80 & & \\
\hline Residual variable effect & 0.45 & & \\
\hline
\end{tabular}

Correlation coefficient signs between direct and indirect effects point out Rs intensification with $\mathrm{R}$ reduction. It might have occurred due to cloudiness decrease, which promotes increasing $\mathrm{T}_{\max }$ and, consequently, $\mathrm{RH}_{\mathrm{m}}$ values since they behave inversely proportional along the day. Taken together, direct and indirect effects of these meteorological variables explained $80 \%$ variability of milk performance.

Identifying the meteorological variable of major influence on milk yield enabled the setting up of a simple nonlinear mathematical model for production estimate ( $\mathrm{kg}$ milk per day) as a function of $\mathrm{T}_{\max }$. The model fitted to 'Saanen' breed was sigmoidal with a coefficient of determination (0.81) close to that verified in the path analysis (0.80). This outcome testifies that, individually, this variable can be used to estimate the milk production of such animals (Figure 1). 


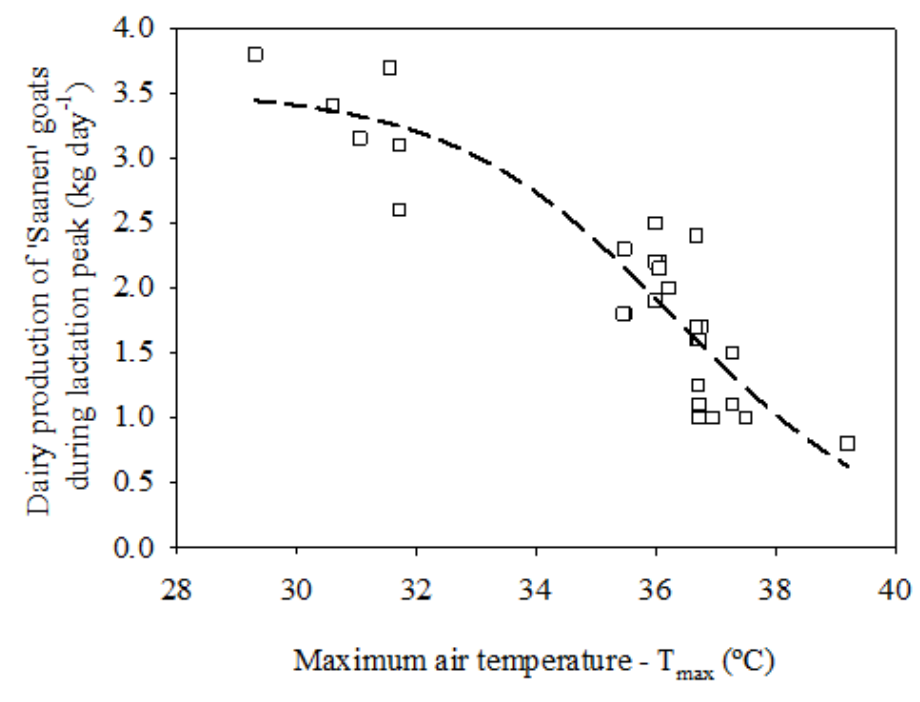

$\mathrm{pl}($ peak-Saanen $)=3.5217 /(1+\exp (-($ tmáx -36.3284$) /-1.8754)) \quad \mathrm{R}^{2}=0.81$

FIGURE 1. Simple mathematical model for milk production estimates during lactation peak of 'Saanen' dairy goats as a function of maximum air temperature. Modelo matemático simples para estimativa da produção de leite durante a fase de pico de lactação em função da temperatura máxima do ar para caprinos leiteiros da raça Saanen.

A sigmoidal model denotes a slight drop in milk production up to $33{ }^{\circ} \mathrm{C}\left(0.1 \mathrm{~kg} /{ }^{\circ} \mathrm{C}\right)$, but after that it becomes sharp $\left(0.3 \mathrm{~kg} /{ }^{\circ} \mathrm{C}\right)$ until near $39{ }^{\circ} \mathrm{C}$, i.e. an upper critical limit for the breed concerned. By model extrapolation, a slow decrease again $\left(0.1 \mathrm{~kg} /{ }^{\circ} \mathrm{C}\right)$ is evidenced between 39 and $45^{\circ} \mathrm{C}$.

A few authors have reported the sensitivity of 'Saanen' goats to the semi-arid conditions (LOPES et al., 2012; ROBERTO et al., 2012). However, the great milk production levels at temperatures considered stressful, being harmful even for indigenous breeds (LUCENA et al., 2013), demonstrated the ability of such breed to adapt to this environment.

Using this mathematical model for the climate database of the Brazilian Northeast, we could point out that milk production at lactation peak was favored between January and June, in almost the entire region. Over these months, mean maximum air temperatures are generally below $32{ }^{\circ} \mathrm{C}$ (Figure 2).

Under these conditions, dairy production can reach levels above $3.0 \mathrm{~kg} \mathrm{day}^{-1}$, implying in animal thermal comfort emphasized by a propitious milk production (MAC-LEAN et al., 2011). However, the result seen here is below that found by RANGEL et al. (2012), who recorded a mean production of $5.4 \mathrm{~kg} \mathrm{day}^{-1}$ during peak lactation, for confined animals.

Although goats are able to maintain milk production capacity and disease resistance when under thermal stress (ESCARENO et al., 2013), there was a downward trend in productivity for some states from August to December. It was because the increase in $T_{\max }$ restricted milk production to a maximum of $3.0 \mathrm{~kg} \mathrm{day}^{-1}$. 


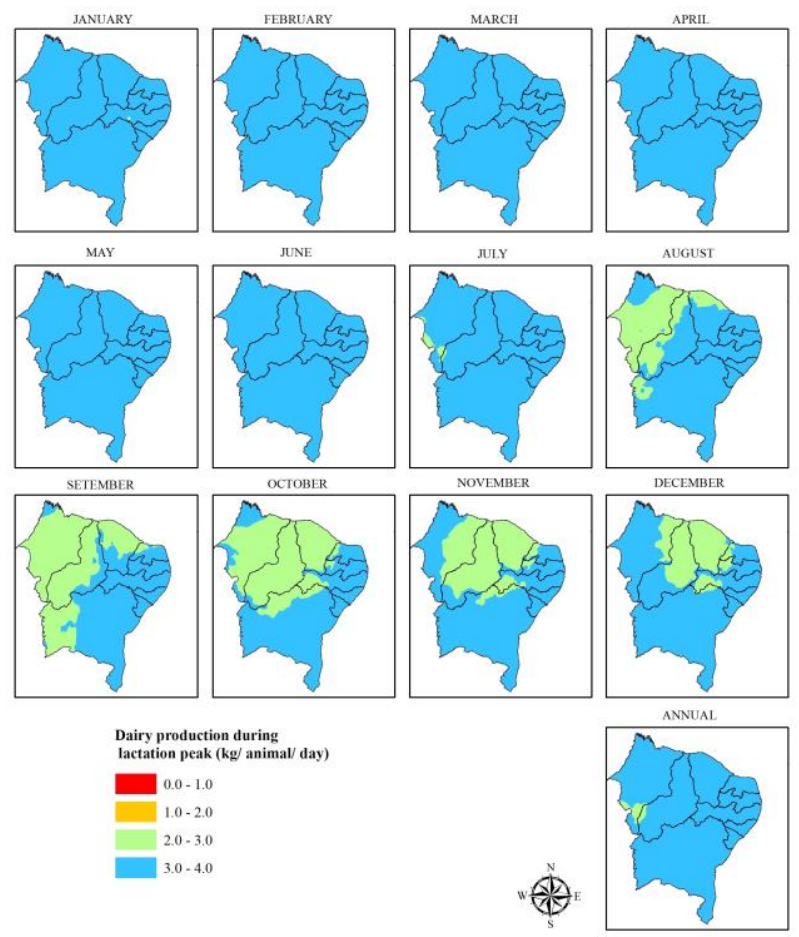

FIGURE 2. Bioclimatic zoning of Northeastern Brazil for 'Saanen' dairy goats in different months of the year. Zoneamento bioclimático da região Nordeste brasileira para caprinos leiteiros da raça Saanen nos diferentes meses do ano.

Production losses due to the thermal increase were mostly evident in the states of Maranhão, Piauí, Ceará, and western Bahia, from August to September, and in western Pernambuco from October to December. Nevertheless, the region owns a good productive capacity since it may reach values between 2.0 and $3.0 \mathrm{~kg}$ milk day $^{-1}$. These data are similar to the findings of ZAMBOM et al. (2011), in Maringá - Paraná state, and those of PEREIRA et al. (2011).

However, these conditions may be further intensified with future climatic projections of $\mathrm{T}_{\max }$ increase. Given the thermal increase of $3.8^{\circ} \mathrm{C}$, in scenario $\mathrm{B} 2$, milk production tends to decrease markedly due to the sensitivity of animals to temperature increases above $33^{\circ} \mathrm{C}$ (Figure 3 ).

In this scenario, Maranhão and Piauí states are more likely to reduce levels of milk production drastically, reaching, from October to November, values below $1.0 \mathrm{~kg} \mathrm{day}^{-1}$. Therefore, in this scenario, it would be recommended to adopt management and facilities able to mitigate the effect of such thermal stress on animals (SOUZA et al., 2011).

The areas of Chapada Diamantina, South Central and Southern Bahia, in addition to Pernambuco and Alagoas Agreste regions, even under B2 scenario conditions, with temperature rise, maintained milk production for most of the year within a range of 3.0 to $4.0 \mathrm{~kg}$ milk day ${ }^{-1}$. This outcome highlights the feasibility of breeding these animals in a short to medium term upon a climate change scenario. 

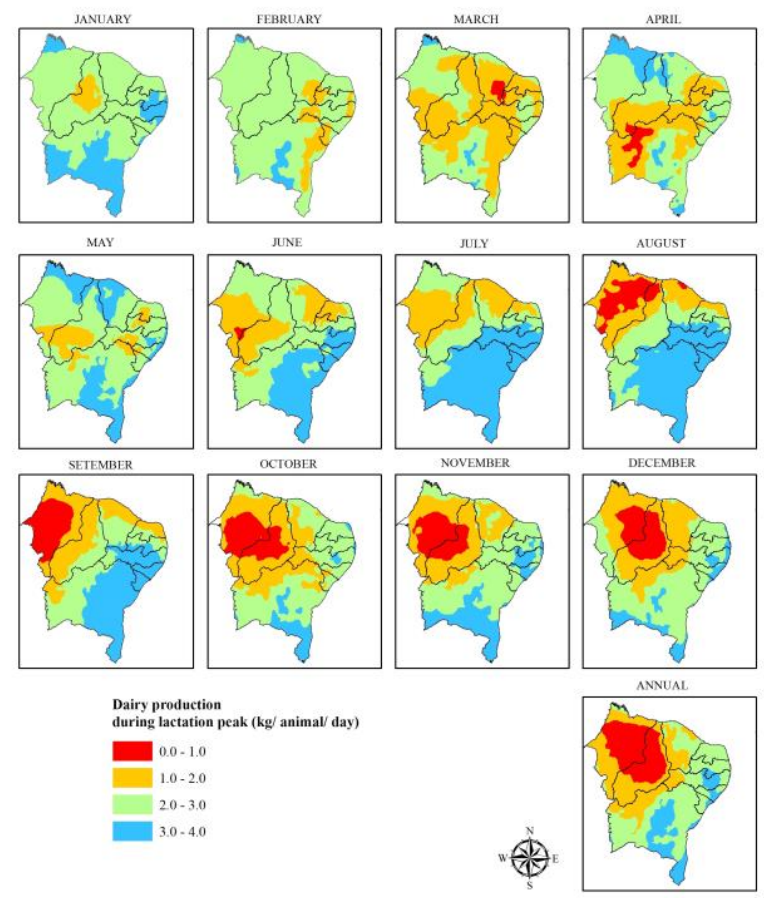

FIGURE 3. Dairy production future projections for 'Saanen' goats based on increasing values of maximum air temperature, estimated in scenario B2 from SRES IPCC, in the different months of the year for northeastern Brazil. Projeções futuras para produção de leite de cabras Saanen, baseado no incremento de temperatura máxima do ar cenário B2 do SRES IPCC, nos diferentes meses do ano para a região Nordeste do Brasil.

On the other hand, based on scenario $\mathrm{A} 2$, with an increase of $6.8^{\circ} \mathrm{C}$, milk production during peak lactation will be strongly compromised with milk yields below $1.0 \mathrm{~kg} \mathrm{day}^{-1}$ in the states of Piauí and Maranhão during almost all the year, and in Ceará from December to June (Figure 4).

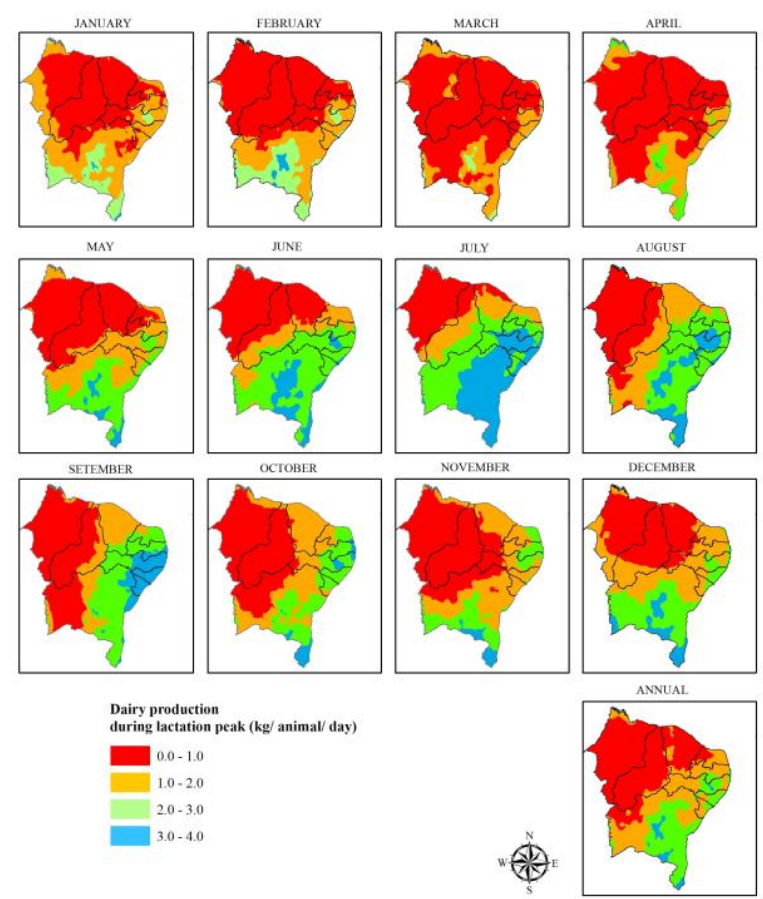

FIGURE 4. Dairy production future projections for 'Saanen' goats based on increasing values of maximum air temperature, estimated in scenario A2 from SRES IPCC, in the different months of the year for northeastern Brazil. Projeções futuras para produção de leite de cabras Saanen, baseado no incremento de temperatura máxima do ar do cenário A2 do SRES IPCC, nos diferentes meses do ano para a região Nordeste do Brasil. 
The states of Alagoas and Sergipe underwent major drops in milk production throughout the year, yielding from 1.0 to $2.0 \mathrm{~kg} \mathrm{day}^{-1}$ between March and April, with values above $3.0 \mathrm{~kg} \mathrm{day}^{-1}$ only in September. Even under a scenario of increased $T_{\max }$, production levels above $2.0 \mathrm{~kg}$ day ${ }^{-1}$ could be seen in regions such as Chapada Diamantina, Southern and South Center Bahia, as well as Pernambuco Agreste regions.

Studying impacts of climatic changes under scenarios B2 and A2, SILVA et al. (2009) endorsed the adoption of air conditioning techniques as evaporative adiabatic cooling systems to minimize heat stress on animals once this system favors thermal comfort by reducing environmental temperature, resulting in a higher milk production.

More affordable alternatives, such as ventilated areas, east-west-built facilities, use of ceiling panels near the roof, high ceilings, and ceramic tiles (SAMPAIO et al., 2011; TURCO et al., 2011), are efficient to reduce the inner temperatures, being thus recommended for improvement of thermal conditions and animal welfare.

\section{CONCLUSIONS}

1. The sigmoidal model showed a marked reduction trend in milk production for 'Saanen' goats if subjected to temperatures above $33^{\circ} \mathrm{C}$.

2. Taking into account the meteorological variables, Chapada Diamantina, Southern and Extreme South Bahia state, as well as Agreste areas of Pernambuco state, have great potential for dairy production of 'Saanen' goats, even under climate changing scenarios B2 and A2.

\section{ACKNOWLEDGEMENTS}

The authors thank the Embrapa Caprinos e Ovinos for the grating of the database for this research.

\section{REFERENCES}

BRISTOW, K.L.; CAMPBELL, G.S. On the relationship between incoming solar radiation and daily maximum and minimum temperature. Agricultural and Forest Meteorology, Pullman, v.31, n.2, p.159-166, 1984.

BUFFINGTON, C.S.; COLLAZO-AROCHO, A.; CANTON, G.H.; PITT, D. Black globe humidity comfort index for dairy cows. St. Joseph: ASAE, 1977. 19p.

CAVALCANTI, E.P.; SILVA, V.P.R.; SOUSA, F.A.S. Programa computacional para a estimativa da temperatura do ar para a região Nordeste do Brasil. Revista Brasileira de Engenharia Agrícola e Ambiental, Campina Grande, v.10, n.1, p.140-147, 2006.

CRUZ, C.D. GENES - a software package for analysis in experimental statistics and quantitative genetics. Acta Scientiarum. Agronomy, Maringá, v.35, n.3, p.271-276, 2013.

ESCARENO, L.; SALINAS-GONZALEZ, H.; WURZINGER, M.; INIGUEZ, L.; SOELKNER, J.; MEZA-HERRERA, C. Dairy goat production systems. Tropical Animal Health and Production, Edinburgh, v.45, n.1, p.17-34, 2012.

GEROSA, S.; SKOET, J. Milk availability: trends in production and demand and medium-term outlook. New York: Agricultural Development Economics Division, Food and Agriculture Organization of the United Nations, 2012. 38p. (ESA Working Paper $n^{\circ} 12-01$ ).

LOPES, J.J.; SOUZA, B.B.D.; SILVA A.M.A.; BATISTA N.L.; NOBRE. I.S. Efeito do ambiente sobre as respostas fisiológicas de caprinos Saanen e seus mestiços com a raça Boer no semiárido paraibano. Agropecuária Científica no Semiárido, Patos, v.8, n.3, p.83-89, 2012. 
LUCENA, L.F.A.; FURTADO, D.A.; NASCIMENTO, J.W.B.; MEDEIROS, A.N.; SOUZA, B.B. Respostas fisiológicas de cabras Anglonubianas a condições ambientais com temperatura elevada. Revista Brasileira de Engenharia Agrícola Ambiental, Campina Grande, v.17, n.6, p.672-679, 2013.

MAC-LEAN, P.A.B.; BARBOSA, O.R.; JOBIM, C.C.; GASPARINO, E.; SANTOS, G.T.; FARIA, L.A.N. Sombra artificial e método de fornecimento de concentrado no comportamento e desempenho de bezerros desmamados. Acta Scientiarum. Animal Sciences, Maringá, v.33, n.4, p.409-415, 2011.

MENDES, A.M.D.P.; AZEVEDO, M.D.; LOPES, P.M.O.; MOURA, G.B.D.A. Bioclimatic zoning for Dorper sheep in the state of Pernambuco, Brazil. Pesquisa Agropecuária Brasileira, Brasília, DF, v.49, n.12, p.986-993, 2014.

NAKICENOVIC, N.; SWART, R. (Ed.). Special report on emission scenarios. Cambridge: Cambridge University Press, 2000. P. 612.

PEREIRA, G.M.; SOUZA, B.B.; SILVA, A.M.A.; ROBERTO, J.V.B.; SILVA, C.M.B.A. Avaliação do comportamento fisiológico de caprinos da raça Saanen no semiárido paraibano. Revista Verde, Pombal, v.6, n.1, p.83-88, 2011.

RANGEL, A.H.N.; PEREIRA, T.I.C.; ALBUQUERQUE NETO, M.C.; MEDEIROS, H.R.; ARAÚJO, V.M.; NOVAIS, L.P.; ABRANTES, M.R.; LIMA JÚNIOR, D.M. Produção e qualidade do leite de cabras e torneios leiteiros. Arquivos do Instituto Biológico, São Paulo, v.79, n.2, p.145-151, 2012.

ROBERTO, J.V.B.; MARQUES B.A.A.; SOUZA, B.B.; AZEVEDO S.S.; NETO D.Y.C.A. Caroço de algodão na dieta de cabras saanen no semiárido paraibano. Revista Brasileira de Saúde e Produção Animal, Salvador, v.13, n.1, p.271-282, 2012.

SAMPAIO, C.A.P.; CARDOSO, C.O.; SOUZA, G.P. Temperaturas superficiais de telhas e sua relação com o ambiente térmico. Engenharia Agrícola, Jaboticabal, v.31, n.2, p. 230-236, 2011.

SANTOS, F.S.M.D.; PIRES, J.E.P.; PEREIRA, A.M.; AZEVEDO, D.M.M.R.; ROCHA, R.R.C.; CARDOSO, F.S.; ARAUJO, A.M. MURATORI, M.C.S.;

COSTA, A.P. R. Adaptabilidade de caprinos Sannen e Marota mantidos em clima tropical semiúmido. Revista Brasileira de Saúde e Produção Animal, Salvador, v.15, n.4, p.928-936. 2014.

SILVA, C.M.B.A.; SOUZA; B.B.; BRANDÃO, P.A.; MARINHO, P.V.T.; BENÍCIO, T.M.A. Effect of the semiarid climatic conditions on the physiological behavior of F1 Saanen $x$ Boer crossbred goats. Revista Caatinga, Mossoró, v.24, n.4, p.195-199, 2011.

SILVA, T. G. F.; MOURA, M. S. B.; SÁ, I. I. S.; ZOLNIER, S.; TURCO, S. H. N.; JUSTINO, F.; CARMO, J. F. A.; SOUZA, L. S. B. Impactos das mudanças climáticas na produção leiteira do estado de Pernambuco: análise para os cenários de B2 e A2 do IPCC. Revista Brasileira de Meteorologia, São Joé dos Campos, 24, n.4, p.489-501, 2009.

SILVA, T.G.F.; ZOLNIER, S.; MOURA, M.S.B.; SEDIYAMA, G.C. Estimativa e espacialização da umidade relativa do ar para os estados de Alagoas, Bahia e Sergipe. Revista Brasileira de Agrometeorologia, Piracicaba, v. 15, n.1, p.14-28, 2007.

SOUZA, B.B.; ASSIS, D.Y.C.; SILVA NETO, F.L.; ROBERTO, J.V.B.; MARQUES, B.A.A. Efeito do clima e da dieta sobre os parâmetros fisiológicos e hematológicos de cabras da raça saanen em confinamento no sertão paraibano. Revista verde, Pombal, v.6, n.1, p.77-82, 2011.

THOM, E.C. The discomfort index. Weatherwise, Omaha, v.12, n.1, p.57-60, 1959.

THOMAZ, G.L.; ZAGONEL, J.; COLASANTE, L.O.; NOGUEIRA, R.R. Produção do girassol e teor de óleo nos aquênios em função da temperatura do ar, precipitação pluvial e radiação solar.

Ciência Rural, Santa Maria, v.42, n.8, p.1380-1385, 2012. 
TURCO, S.H.N.; AZEVEDO, D.M.M.R.; OLIVEIRA, P.T.L. Ambiente e a produção de caprinos e ovinos. In: VOLTOLINI, T.V. (Ed.). Produção de caprinos e ovinos no Semiárido. Petrolina: EMBRAPA Semiárido, Brasília: Embrapa Informação Tecnológica 2011, p.145-163.

TURCO, S.H.N.; SILVA, T.G.F.; OLIVEIRA, G.M.; LEITÃO, M.M.V.B. R.; MOURA, M.S.B.; PINHEIRO, C.; PADILHA, C.V.S. Estimating black globe temperature based on meteorological data. In: INTERNATIONAL CONFERENCE OF AGRICULTURAL

ENGINEERING; BRAZILIAN CONGRESS OF AGRICULTURAL ENGINEERING, 37.;

INTERNATIONAL LIVESTOCK ENVIRONMENT SYMPOSIUM, 8., 2008, Foz do Iguaçu.

Proceedings... Foz do Iguaçu: SBEA, 2008. CD ROM.

VIANELLO, R.L.; ALVES, A.R. Meteorologia básica e aplicações. 2.ed. Viçosa: Ed. da UFV, 2012. 460p.

ZAMBOM, M.A.; ALCALDE, C.R.; SILVA, K.T.; MACEDO, F.A.F.; RAMOS, C.E.C.O.;

GARCIA, J.; HASHIMOTO, J.H.; LIMA, L.S. Produção e qualidade do leite de cabras alimentadas com casca do grão de soja em substituição ao milho moído. Revista Brasileira de Saúde e Produção Animal, Salvador, v.12, n.1, p.126-139, 2011.

WRIGHT, S. Correlation and causation. Journal Agriculture Research, Collingwood, v.20, p.557-585, 1921. 